\title{
You're Such A Burden, COVID-19! Psychological Impact among Postgraduate Students in Malaysia
}

\section{Muhammad Wafi Ramli, Mohammad Izzamil Mohd Nasir \& Sofia Haminah} Mohd Som

To Link this Article: http://dx.doi.org/10.6007/IJARBSS/v11-i4/9022

DOI:10.6007/IJARBSS/v11-i4/9022

Received: 11 February 2021, Revised: 16 March 2021, Accepted: 31 March 2021

Published Online: 08 April 2021

In-Text Citation: (Ramli et al., 2021)

To Cite this Article: Ramli, M. W., Nasir, M. I. M., \& Som, S. H. M. (2021). You're Such A Burden, COVID-19! Psychological Impact among Postgraduate Students in Malaysia. International Journal of Academic Research in Business and Social Sciences, 11(4), 37-52.

\section{Copyright: @ 2021 The Author(s)}

Published by Human Resource Management Academic Research Society (www.hrmars.com)

This article is published under the Creative Commons Attribution (CC BY 4.0) license. Anyone may reproduce, distribute, translate and create derivative works of this article (for both commercial and non-commercial purposes), subject to full attribution to the original publication and authors. The full terms of this license may be seen at: http://creativecommons.org/licences/by/4.0/legalcode

Vol. 11, No. 4, 2021, Pg. 37 - 52

Full Terms \& Conditions of access and use can be found at http://hrmars.com/index.php/pages/detail/publication-ethics 


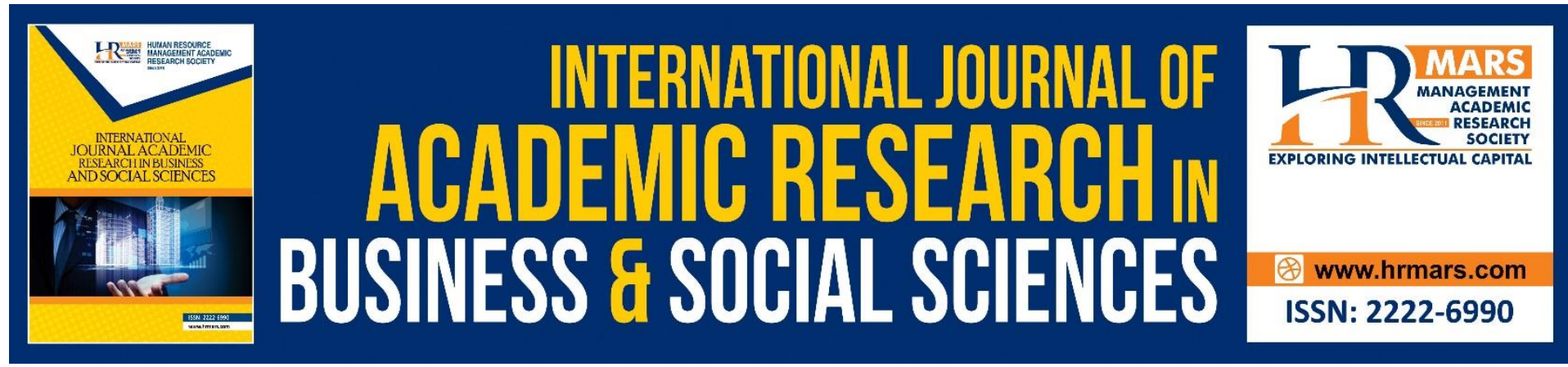

\title{
You're Such A Burden, COVID-19! Psychological Impact among Postgraduate Students in Malaysia
}

\author{
Muhammad Wafi Ramli, Mohammad Izzamil Mohd Nasir \& \\ Sofia Haminah Mohd Som
}

Geography Section, School of Humanities, Universiti Sains Malaysia, 11800 Penang, Malaysia Email: wafiramli22@gmail.com

\begin{abstract}
The COVID-19 pandemic has given significant impacts on students around the world. This pandemic had caused the closure of higher education institutions (HEIs), hence affecting the psychological well-being of the students. Currently, little is known about the psychological impact of the pandemic upon tertiary-level students. Therefore, this study aims to identify the psychological impact of the pandemic among postgraduate students in Malaysia, as well as to determine the relationship between psychological impact of the pandemic with postgraduate students' socio-demographic. An online survey through Google Form is conducted and participated by a total of 606 postgraduate students from different backgrounds. The findings indicate that most postgraduate students experienced panic and nervousness when thinking about their studies and feeling dejected with their academic progress. This study also reveals that the postgraduate student's socio-demographic (age, monthly income, source of income, study program, mode of study, and year of study) have significant relationship with psychological impact of the pandemic. This study is urgently vital for HEls and relevant government agencies to assist them in formulating suitable policies and strategies in order to maintain a healthy psychological environment for postgraduate students amidst the pandemic.
\end{abstract}

Keywords: COVID-19 Pandemic, Impact, Postgraduate Student, Psychology, Malaysia

\section{Introduction}

The COVID-19 outbreak first occurred in Wuhan, China in December 2019 and the rapid spread of this disease called the World Health Organization (WHO) to declare it as pandemic on 11 March 2020 (WHO, 2020). Since then, HEls around the world were obligated to close their campuses so that students could follow social distancing measures and minimize gatherings in order to decrease the transmission of the virus (Toquero, 2020; Mahdy, 2020). Thus, education at all levels, including both undergraduate and postgraduate levels, had been significantly affected, interrupting the learning of more than one billion students in 129 countries around the globe (Mostafa, 2020; UNESCO, 2020). This situation had challenged the education systems worldwide, causing HEls to rapidly change their traditional face-to-face classes to online classes (Abelskamp \& Santamarinam, 2020). Most countries have stopped face-to-face teaching (UNESCO IESALC, 2020) and currently replacing it with online solutions 
wherever practicable (Gonzalez et al., 2020), which has been a challenging task to do (Mahmood, 2020). The end date of the pandemic is yet to be discovered, therefore educational institutions around the world have decided to use available technical resources to create online learning materials for students from all academic fields (Kaur, 2020).

According to Kapasia et al (2020), the closure of educational institutions due to the pandemic has led to an unprecedented impact on education, which also posed a threat to psychological health such as stress, depression and anxiety among HEls students (Khan et al., 2020; Mpungose, 2020). Many students are affected worldwide and there is a fear of losing this whole ongoing semester or even more in the upcoming future (Dhawan, 2020). Aristovnik et al. (2020) stated that students are among the population groups that had experienced dramatic effects of the first wave of the pandemic in the first 4 or 5 months of 2020, therefore causing huge changes in their everyday lives, and perhaps even more alarmingly, to the prospects of their immediate and distant future. The most commonly reported psychological challenges include fear, worries, loss of confidence, anxiety, stress, loss of interest, sense of worthlessness, and tension. It is also found that psychological problems associated to COVID19 include feeling of discomfort, hopelessness, sleep instability, reluctance, mental ignorance, mental state disturbances, confusion, feeling insecure, mistrust, and inability to control problems (Fura \& Negash, 2020).

Malaysia has been facing the threat of COVID-19 since the emergence of the first cluster, which was detected on 24 January 2020 (Ramli \& Jamri, 2021; Hamid et al., 2021), involving a tourist from China who arrived in Johor through the gates of Singapore (Siplan \& Holems, 2020). Since then, the number of COVID-19 infection cases continued to rise in each state in the following months (Dawood et al., 2020). Currently, as of 22 March 2021, Malaysia has reported 334,156 cases and 1238 death cases (Ministry of Health Malaysia, 2021). In attempt to control the spreading of the pandemic, the Malaysian government had declared Movement Control Order (MCO) on 18 March 2020, followed by Enhanced Movement Control Order (EMCO) on 27 March 2020, Semi Enhanced Movement Control Order (SEMCO) on 14 May 2020, Conditional Movement Control Order (CMCO) on 1 May 2020, and Recovery Movement Control Order (RMCO) phase which started on 10 June 2020 and scheduled to 31 December 2020 (Nasir et al., 2021). Recently, the government announced that the RMCO will be extended until 31 March 2021, and the King of Malaysia, Al-Sultan Abdullah Ri'ayatuddin Al-Mustafa Billah Shah Ibni Sultan Haji Ahmad Shah Al-Musta'in Billah has declared a state of emergency across the country which is scheduled to last until 1 August 2021, unless cases were brought under control earlier (BBC News, 2021). As a measure to reduce the spread of the pandemic, most HEls in Malaysia are closed and they are limiting the number of student admission. Currently, the process of teaching and learning are conducted online until a time that will be determined later by the Ministry of Higher Education Malaysia (MoHE) (Shahzad et al., 2020). According to Sundaren et al. (2020), although measures such as lockdown, strict isolation, social distancing, emergency remote teachings have primarily reduced the spread of COVID-19 in Malaysia, the uncertainty and delay in the commencement of HEls are significantly affecting students' psychological well-being.

To date, only a few studies on the impact of COVID-19 towards HEls students in Malaysia have been conducted. Previous studies have focused on online teaching and learning for tertiary education (Chung et al., 2020; Nik-Ahmad-Zuky et al., 2020; Salleh et al., 2020), perception of e-learning (Ana et al., 2020), and online purchase intention among HEls students (Al-Hassani et al., 2020). However, studies focusing on the psychological impact of COVID-19 among students in Malaysia, especially focusing on the postgraduate students are 
yet to be conducted. Studies investigating the impact of COVID-19 on students' psychology are notably needed (Grubic et al., 2020). Accordingly, this study aims to identify the psychological impact of the COVID-19 pandemic among postgraduate students, as well as to determine the relationship between psychological impact of the pandemic with postgraduate students' socio-demographic. The findings of this study are expected to extend the current literature and to provide insights for Malaysian HEls in assisting postgraduate students at times like this in the future.

\section{Hypothesis}

Based on previous research study related to psychological impact, Lan et al. (2020), Mokhtari et al. (2015) and lqbal et al. (2015) agreed that socio-demographic also influence the psychological impact among students. Therefore, there will be 13 sub-hypotheses to be tested which are:

H 1.1 : There is significant correlation between nationality and psychological impact among postgraduate students

H 1.2 : There is significant correlation between gender and psychological impact among postgraduate students

H 1.3 : There is significant correlation between age and psychological impact among postgraduate students

H 1.4 : There is significant correlation between level of education and psychological impact among postgraduate students

H 1.5 : There is significant correlation between monthly income and psychological impact among postgraduate students

H 1.6 : There is significant correlation between source of income and psychological impact among postgraduate students

H 1.7 : There is significant correlation between study program and psychological impact among postgraduate students

H 1.8 : There is significant correlation between mode of study and psychological impact among postgraduate students

H 1.9 : There is significant correlation between year of study and psychological impact among postgraduate students

H 1.10 : There is significant correlation between field of study and psychological impact among postgraduate students

H 1.11 : There is significant correlation between type of HEls and psychological impact among postgraduate students

H 1.12 : There is significant correlation between region of HEls and psychological impact among postgraduate students

H 1.13 : There is significant correlation between residential area and psychological impact among postgraduate students

\section{Methods}

\section{Participants and Instrument}

This study is carried out using convenience and purposive sampling method, involving 606 respondents comprising of postgraduate students in Malaysia. An online survey form is used as the instrument to obtain the primary data. The questionnaire consists of two constructs, namely (i) respondents' socio-demographic information, including nationality, age, gender, 
monthly income, source of income, level of education, types, mode and year of study, field of study, type of HEls, region of HEls, and residential area, and (ii) the psychological impact of the pandemic among Malaysian postgraduate students. The instrument is originally developed based on a study by Sharma and Devkota (2019) and adapted to suit the context of the present study. This instrument employs a Likert-type scale of 1-5; " 1 = Strongly Disagree", " 2 = Disagree", " 3 = Not Sure", " 4 = Agree", " 5 = Strongly Agree". The survey form is created using Google Forms and distributed online. The distribution is done by sharing the Google Forms link to all postgraduate students via email, WhatsApp, Twitter, and Facebook. A standardised general description about the survey is provided in the social media postings and WhatsApp messages, both in Malay and English versions of the questionnaire. All respondents are asked to participate in the survey voluntarily without coercion and assured that their anonymity and confidentiality will always be maintained.

\section{Statistical Analysis}

The data are analysed using IBM Statistical Package for the Social Sciences (SPSS) software version 26.0. A significant part of the data are analysed using descriptive statistical analysis to obtain the values of frequency, percentage, mean, standard deviation, and bivariate correlation analysis. The interpretation scale by Landell (1997) is applied to determine the level of score for each mean value, namely low (1.00 - 2.33), moderate (2.34 - 3.67) and high (3.68 - 5.00). A correlation analysis is then performed to test the relationship between all socio-demographic characteristics with the psychological impact of the pandemic among Malaysian postgraduate students. The analysis and tabulation of data are presented in each section accordingly.

\section{Result and Discussion \\ Respondent's Socio-demographic}

Table 1 shows the socio-demographic of the respondents. $97.2 \%$ are Malaysians, while the other $2.8 \%$ are non-Malaysians. The respondents are predominantly female $(75.9 \%)$ in comparison to male (25.1\%). The findings show that a large number of the respondents (32.8\%) are between $26-30$ years old, followed by $26.9 \%$ aged between $31-35$ years old, and 14.2\% aged between 36-40 years old. As for their levels of education, 59.7\% are Ph.D. students, while the other $40.3 \%$ of the are master's degree students, in which $73.8 \%$ are in research mode, $16.2 \%$ in coursework mode, and the rest in mix-mode $(10.1 \%)$. In the distribution of the monthly income, majority of the respondents $(71.5 \%)$ are from the B40 (bottom $40 \%$ - less than MYR 4,850) income group, followed by $25.1 \%$ from the M40 (Middle $40 \%$ - between MYR 4,851 and MYR 10,959) income group, and 3.5\% from the T20 (Top 20\% - more than MYR 10,959) income group. Other demographic characteristics are detailed in Table 1. 
Table 1. Respondents' socio-demographic

\begin{tabular}{|c|c|c|}
\hline Variable & $\begin{array}{c}\text { No. of } \\
\text { Respondents }\end{array}$ & $\begin{array}{c}\text { Percentage } \\
\text { (\%) }\end{array}$ \\
\hline \multicolumn{3}{|l|}{ Nationality } \\
\hline Malaysian & 589 & 97.2 \\
\hline Non-Malaysian & 17 & 2.8 \\
\hline \multicolumn{3}{|l|}{ Gender } \\
\hline Male & 152 & 25.1 \\
\hline Female & 454 & 74.9 \\
\hline \multicolumn{3}{|l|}{ Age (years old) } \\
\hline$<25$ & 84 & 13.9 \\
\hline $26-30$ & 199 & 32.8 \\
\hline $31-35$ & 163 & 26.9 \\
\hline $36-40$ & 86 & 14.2 \\
\hline $41-45$ & 51 & 8.4 \\
\hline $46-50$ & 15 & 2.5 \\
\hline$>50$ & 8 & 1.3 \\
\hline \multicolumn{3}{|l|}{ Level of Education } \\
\hline Master's Degree & 244 & 40.3 \\
\hline Ph.D. & 362 & 59.7 \\
\hline \multicolumn{3}{|l|}{ Monthly Income } \\
\hline B40 (< MYR 4850) & 433 & 71.5 \\
\hline M40 (MYR 4851 - 10959) & 152 & 25.1 \\
\hline T20 (< MYR 10959) & 21 & 3.5 \\
\hline \multicolumn{3}{|l|}{ Source of Income } \\
\hline Part-time job & 62 & 10.2 \\
\hline Full time job & 185 & 30.5 \\
\hline Scholarship & 152 & 25.1 \\
\hline Study loan & 62 & 10.2 \\
\hline Family/Spouse & 145 & 23.9 \\
\hline \multicolumn{3}{|l|}{ Program } \\
\hline Coursework & 98 & 16.2 \\
\hline Mix-mode & 61 & 10.1 \\
\hline Research & 447 & 73.8 \\
\hline \multicolumn{3}{|l|}{ Mode of Study } \\
\hline Full time & 489 & 80.7 \\
\hline Part-time & 117 & 19.3 \\
\hline \multicolumn{3}{|l|}{ Year of Study } \\
\hline 1 & 157 & 25.9 \\
\hline 2 & 205 & 33.8 \\
\hline 3 & 133 & 21.9 \\
\hline 4 & 52 & 8.6 \\
\hline 5 & 59 & 9.7 \\
\hline \multicolumn{3}{|l|}{ Field of Study } \\
\hline Engineering & 70 & 11.6 \\
\hline Health & 52 & 8.6 \\
\hline
\end{tabular}




\begin{tabular}{lcc}
\hline Applied Science & 106 & 17.5 \\
\hline Pure Science & 59 & 9.7 \\
\hline Pure Arts & 36 & 5.9 \\
\hline Applied Arts & 43 & 7.1 \\
\hline Others & 240 & 39.6 \\
\hline Type of HEls & & \\
\hline Public & 570 & 94.1 \\
\hline Private & 36 & 5.9 \\
\hline Region of HEls & & \\
\hline East Coast of Peninsular Malaysia & 44 & 7.3 \\
\hline Sabah/Sarawak & 43 & 7.1 \\
\hline Southern of Peninsular Malaysia & 72 & 11.9 \\
\hline Central & 293 & 48.3 \\
\hline Northern of Peninsular Malaysia & 154 & 25.4 \\
\hline Residential Area & & \\
\hline Urban area & 474 & 78.2 \\
\hline Rural area & 132 & 21.8 \\
\hline
\end{tabular}

\section{Psychological Impact of the Pandemic among Postgraduate Students}

Table 2 shows the mean score and level of psychological impact of postgraduate students in Malaysia during the pandemic. Based on the table, most respondents experienced a moderate level of agreement on their psychological impact involving low self-esteem, sleep problems, lack of self-confidence, lack of appetite, and feeling of loneliness. However, there are two statements that show a high level of agreement. A prominent number of respondents agree with the statement "I feel panic and nervous when I think about my studies", with ( $\mu=$ $4.06, S D=1.19)$. This is believed to be influenced by the situation where most respondents had to face a relatively long period of isolation, which started in mid-March 2020 until now. The quarantine period has had a huge impact on postgraduate students as it directly affects the continuity of their studies. To date, many postgraduate students are still struggling with inconsistent learning conditions, such as having difficulty adapting to online learning and difficulty in accessing a stable internet connection, especially those living in rural areas. This finding is in line with a study by Kapasia et al. (2020) and Mahdy (2020), where they reported that the problems faced by HEls students include poor internet connectivity, which then affects their completion of assignments, presentations, publications and so on, on top of the existing difficulties that emerge during this pandemic period. This caused them to feel panic and nervous when thinking about their studies, especially when the challenge and barrier to their academic survival are intensified by the pandemic. This finding is also consistent with a study by Fura and Negash (2020), in which participants expressed fear and worry about continuing their education online especially during the first phase of the pandemic, where the lack of sufficient internet access to help them receive education materials are some of the reported challenges. 
Table 2. The mean, standard deviation, and level of psychological impact during pandemic

\begin{tabular}{|c|c|c|c|}
\hline Items & Mean & $\begin{array}{l}\text { Standard } \\
\text { Deviation }\end{array}$ & Level \\
\hline $\begin{array}{l}\text { I feel panic and nervous when I think about } \\
\text { my studies }\end{array}$ & 4.06 & 1.19 & High \\
\hline $\begin{array}{l}\text { I always feel unhappy with my study/research } \\
\text { progress }\end{array}$ & 3.78 & 1.26 & High \\
\hline $\begin{array}{l}\text { I feel inferior as compared to my classmates' } \\
\text { study/research }\end{array}$ & 3.57 & 1.41 & Moderate \\
\hline I cannot sleep when I think about my studies & 3.29 & 1.41 & Moderate \\
\hline $\begin{array}{l}\text { I feel less confident when I communicate with } \\
\text { my supervisors/classmates }\end{array}$ & 2.90 & 1.44 & Moderate \\
\hline $\begin{array}{l}\text { I tend to lose my appetite when I think about } \\
\text { my studies }\end{array}$ & 2.88 & 1.39 & Moderate \\
\hline $\begin{array}{l}\text { I prefer to be alone rather than to interact } \\
\text { with my supervisor/classmates }\end{array}$ & 2.73 & 1.44 & Moderate \\
\hline $\begin{array}{l}\text { I tend to take sleeping pills/drugs when I think } \\
\text { about my studies }\end{array}$ & 1.53 & 1.10 & Low \\
\hline
\end{tabular}

Subsequently, the second item that recorded a high mean value is "I always feel unhappy with my study/research progress", with $(\mu=3.78, S D=1.26)$. The respondents agree that they are unhappy with their research progress, especially those who are taking researchbased courses, as their progress reports on the research phases are supposed to be conducted as usual. Despite the obstacles and challenges, the postgraduate students are expected to show progress in their research, or they may be financially penalized or restrained from registering for the upcoming semester. It has been a difficult situation for many postgraduate students due to inability to proceed with their research, especially those who were in the data collection phase involving fieldwork activities, due to the strict movement control order implemented by the government. This is also affecting postgraduate students who require the use of research facilities on campus such as laboratories, library, and workstations, since most HEls have closed such facilities as a measure to prevent the spread of the pandemic. As asserted by Mokhatar (2020), postgraduate students in research who rely on the results of their research through laboratory work or fieldwork are experiencing stress due to the expected completion of thesis and progress report at the end of semester.

Meanwhile, there is a statement that shows a low level of agreement, namely "I tend to take sleeping pills/drugs when I think about my studies", with $(\mu=1.53, \mathrm{SD}=1.10)$. This is motivated by the awareness of respondents about the implications that would occur if they take consume them. Most respondents do not resort to sleeping pills and drugs as the escape from study related problems during the pandemic. This finding is found to be inconsistent with a study by Fura and Negash (2020), who reported that the stress from the pandemic had caused students to consume alcohol and drugs, such as chewing khat. Drug use is also not ideal for students, as it is reported that a high level of drug intake among HEls students will limit their academic performance (Gomez-Galan et al., 2020). 


\section{Psychological Impact of the Pandemic among Postgraduate Students Based on Socio- Demographic}

A bivariate correlation is performed to determine the relationship between psychological impact of the pandemic with socio-demographic among postgraduate students in Malaysia. However, only six (6) socio-demographic factors; namely age, monthly income, source of income, study program, mode of study, and year of study are found significant. The data are presented in Table 3 to Table 8. From this analysis, the result confirms that hypothesis 1.2 , $1.4,1.10,1.11,1.12$, and 1.13 are rejected due to value of ' $p$ ' is more than 0.05 .

\section{Hypothesis 1.3}

Based on Pearson Correlation generated by SPSS, the value $r=-0.117$ ( $p=0.004<0.05)$ is statistically significant. The hypothesis is accepted due to value of ' $p$ ' is less than 0.05 . Therefore, the finding indicates that there is a significant relationship between age and psychological impact among postgraduate students. However, the correlation is negatively weak. These findings show that younger postgraduate students are more likely to deal with the psychological impact of the pandemic. They tend to have higher mental health problems and lower self-esteem (Lee, 2020) while older and more mature students are less likely to have psychological distress (Flesia et al., 2020; Saravanan et al., 2020). This also indicates that older postgraduate students may be able to handle stress better, probably due to a richer life experience. Thus, these findings underscore the need to promote mental health management programmes that will help to enhance younger postgraduate students' psychological wellbeing.

Table 3. Correlation - Age and psychological impact among postgraduate students

\begin{tabular}{llcc}
\hline & & $\mathbf{a}$ & $\mathbf{b}$ \\
\hline aAge & $\begin{array}{l}\text { Pearson } \\
\text { Correlation }\end{array}$ & 1 & $-.117^{* *}$ \\
\hline & Sig. (2-tailed) & & .004 \\
\hline & $\mathrm{N}$ & 606 & 606 \\
\hline $\begin{array}{l}\text { Posychological Impact among } \\
\text { Postgraduate Students }\end{array}$ & $\begin{array}{l}\text { Pearson } \\
\text { Correlation }\end{array}$ & $-.117^{* *}$ & 1 \\
\hline & Sig. (2-tailed) & .004 & \\
\hline & $\mathrm{N}$ & 606 & 606 \\
\hline & $* *$ Correlation is significant at the 0.05 level (2-tailed) &
\end{tabular}

\section{Hypothesis 1.5}

The result in Table 4 shows that the significant value of monthly income is -0.147 ( $p=0.000<$ $0.05)$, suggesting a very weak, negative correlation with the psychological impact of the pandemic, where the impact is higher among postgraduate students whose family earn lower monthly income. Thus, the hypothesis is accepted due to value of ' $p$ ' is less than 0.05 . From the results, consistent with Flesia et al. (2020)' findings, it is clear that lower monthly income may increase the emotional, anxiety, and perceived stress among postgraduate students during the outbreak. Psychological well-being is associated with monthly income. Lower income students might be more concern about the economic effects since due to their financial commitments, such as paying for tuition fees and books. However, Arshad and 
Rafique (2016) reported that monthly income and other control variables such as age and gender may not be a good predictor of psychological well-being.

Table 4. Correlation - Monthly income and psychological impact among postgraduate students

\begin{tabular}{llcc}
\hline & & $\mathbf{a}$ & $\mathbf{b}$ \\
\hline aMonthly Income & $\begin{array}{l}\text { Pearson } \\
\text { Correlation }\end{array}$ & 1 & $-.147^{* *}$ \\
\hline & Sig. (2-tailed) & & .000 \\
\hline $\begin{array}{l}\text { Posychological Impact among } \\
\text { Postgraduate Students }\end{array}$ & $\mathrm{N}$ & 606 & 606 \\
\hline & Pearson & $-.147^{* *}$ & 1 \\
\hline & Correlation & & \\
\hline & $\mathrm{N}$ & .000 & 606 \\
\hline
\end{tabular}

**. Correlation is significant at the 0.05 level (2-tailed)

\section{Hypothesis 1.6}

Table 5 shows the correlation between the source of income and psychological impact of the pandemic among postgraduate students in Malaysia. Based on Pearson Correlation, the value $r=0.126(p=0.002<0.05)$ is statistically significant. The hypothesis is not rejected due to the value of ' $p$ ' is less than 0.05 . Thus, the finding indicates that there is a weak relationship between respondents' source of income and its psychological impact. These findings suggest that students with different sources of income may be psychologically impacted during the pandemic. Majority of students have had their economic activities affected by the pandemic (Armstrong-Mensah et al., 2020). Students enrol in part-time jobs while studying to pay for daily expenses to reduce their economic burden (Nga, 2020). However, they are facing financial stress due to the work limitation as an effect of the pandemic. This situation also has an adverse effect on students who are on scholarships, where almost one-tenth of students and their scholarship payment has either been postponed, cancelled, or reduced (Barada, 2020). Therefore, from this finding, it is acknowledged that postgraduate students are found to be their financially affected, causing psychological distress during the pandemic.

Table 5. Correlation - Source of income and psychological impact among postgraduate students

\begin{tabular}{llcc}
\hline & & $\mathbf{a}$ & $\mathbf{b}$ \\
\hline Source of Income & $\begin{array}{l}\text { Pearson } \\
\text { Correlation }\end{array}$ & 1 & $.126^{* *}$ \\
\hline & Sig. (2-tailed) & .002 \\
\hline $\begin{array}{l}\text { Posychological Impact among } \\
\text { Postgraduate Students }\end{array}$ & $\begin{array}{l}\text { Pearson } \\
\text { Correlation }\end{array}$ & $.126^{* *}$ & 606 \\
\hline & Sig. (2-tailed) & .002 & 1 \\
\hline & $\mathrm{N}$ & 606 & 606 \\
\hline
\end{tabular}




\section{Hypothesis 1.7}

The result in Table 6 shows that the significant value of study program was $0.108(p=0.008<$ $0.05)$, suggesting a very weak, positive correlation with psychological impact of the pandemic. Thus, the hypothesis is accepted due to value of ' $p$ ' is less than 0.05 . From the results, postgraduate students in Malaysia are recognized to be experiencing the psychological impact of the pandemic, regardless of their study program (i.e. coursework, mix-mode, and research). Each program is believed to have its own unique challenge during the pandemic. Thus, postgraduate students are recommended to have personal plans suited to their mode of study, to ensure the continuance of their academic progress while dealing with unexpected situations like this.

Table 6. Correlation - Program and psychological impact among postgraduate students

\begin{tabular}{llcc}
\hline & & $\mathbf{a}$ & $\mathbf{b}$ \\
\hline aStudy Program & $\begin{array}{l}\text { Pearson } \\
\text { Correlation }\end{array}$ & 1 & $.108^{* *}$ \\
& Sig. (2-tailed) & & .008 \\
\hline & $\mathrm{N}$ & 606 & 606 \\
\hline $\begin{array}{l}\text { bPsychological Impact among } \\
\text { Postgraduate Students }\end{array}$ & Pearson & $.108^{* *}$ & 1 \\
\hline & Correlation & & \\
\hline & Sig. (2-tailed) & .008 & 606 \\
\hline & $\mathrm{N}$ & 606 &
\end{tabular}

\section{Hypothesis 1.8}

Based on Pearson Correlation, the value $r=0.119(p=0.003<0.05)$ was positively significant. The hypothesis is accepted due to value of ' $p$ ' is less than 0.05 . Therefore, the finding indicates that there is a weak relationship between the mode of study and psychological impact among postgraduate students. Although there is a relationship between mode of study and psychological impact among postgraduate students, it should be noted that both modes of study have similar needs in the same field, be it full time or part time. For example, full-time students in Geography need to take the same subjects as part-time students. This indicates that, these two modes of study will have an impact that may be more or less the same because there is no difference in their field requirement. 
Table 7. Correlation - Mode of study and psychological impact among postgraduate students

\begin{tabular}{|c|c|c|c|}
\hline \\
\hline & & $\mathbf{a}$ & b \\
\hline \multirow[t]{4}{*}{ aMode of Study } & Pearson & 1 & $.119 * *$ \\
\hline & Correlation & & \\
\hline & Sig. (2-tailed) & & .003 \\
\hline & $\mathrm{N}$ & 606 & 606 \\
\hline${ }^{\text {bPsychological Impact among }}$ & Pearson & $.119 * *$ & 1 \\
\hline \multirow[t]{3}{*}{ Postgraduate Students } & Correlation & & \\
\hline & Sig. (2-tailed) & .003 & \\
\hline & $\mathrm{N}$ & 606 & 606 \\
\hline
\end{tabular}

\section{Hypothesis 1.9}

The result in Table 8 shows that the significant value of year of study was $0.083(p=0.041<$ $0.05)$, suggesting a very weak, positive correlation with the psychological impact of the pandemic, where the impact was higher for the postgraduate students who are in their earliest year of study. Thus, the hypothesis is accepted due to value of ' $p$ ' is less than 0.05 . The finding is found to be inconsistent with a study from Joshi and Nagpal (2019), where they discovered that third year students perceived more stress compared to first year students, possibly due to the additional burden of thesis or dissertation works, accompanied with the uncertainty about their future after graduation. However, all postgraduate students, regardless of their year of study, are prompted to be smart to in dealing with their emotions, stress, and challenges.

Table 8. Correlation - Year of study and psychological impact among postgraduate students

\begin{tabular}{|c|c|c|c|}
\hline & & a & b \\
\hline \multirow[t]{4}{*}{ aYear of Study } & Pearson & 1 & $.083^{*}$ \\
\hline & Correlation & & \\
\hline & Sig. (2-tailed) & & .041 \\
\hline & $\mathrm{N}$ & 606 & 606 \\
\hline${ }^{\text {bPsychological Impact among }}$ & Pearson & $.083^{*}$ & 1 \\
\hline \multirow[t]{3}{*}{ Postgraduate Students } & Correlation & & \\
\hline & Sig. (2-tailed) & .041 & \\
\hline & $\mathrm{N}$ & 606 & 606 \\
\hline
\end{tabular}

\section{Conclusion}

Conclusively, the COVID-19 pandemic has caused a major concern among the psychological well-being of postgraduate students in Malaysia. In this study, we have addressed the psychological impact of the viral outbreak upon postgraduate students through a profound analysis of the survey. The summary of the findings is described as follows.

Firstly, the findings state that most postgraduate students feel panic and nervous when thinking about their studies. Secondly, most postgraduate students are unhappy with 
their study/research progress. Thirdly, most postgraduate students do not resort to sleeping pills/drugs when thinking about their studies. This study has also acknowledged that there is a significant relationship between socio-demographic (age, monthly income, source of income, study program, mode of study, and year of study) with psychological impact of the pandemic among postgraduate students in Malaysia during this outbreak.

This study appeals for Malaysian government and related agencies to start providing extra attention to the psychological well-being of postgraduate students during the pandemic. Government support is critically needed in maintaining a healthy psychological environment for them. Focus could be given to improving internet access in rural areas, which is essential for online learning and research process, such as finding academic materials, participating in forums or seminars, and conducting surveys. Subsequently, HEls could launch a psychological intervention using a digital platform, such as a chat box that enables swift connection between the government and the students. Through such platforms, students can express their concern or ask questions regarding the situation, hence assisting in the development of their psychological well-being. On top of that, HEls could also provide counselling services, either face to face or remotely to be in touch with the students. HEIs ought to embark on structured programs to reduce negative psychological impact, such as life skills training and mindfulness therapy, which has been validated to reduce depression, anxiety, and stress. Comprehensively, the report from this study is reckoned as an important piece of evidence that is hoped to contribute to the improvement of policies and strategies managed by the higher education system in Malaysia.

\section{Acknowledgement}

Acknowledgement is extended to all postgraduate students who were involved as respondents and reviewers for spending their time and effort in reviewing and providing constructive comments to make this study successful. Many thanks to Dr. Mohamed Nazreen Shahul Hamid, Dr. Mohamad Hafifi Jamri, Ms. Nur Syuhada Mustakim, and Ms. Syazana Ayuni Shaharudin, who indirectly helped to make this study successful.

\section{References}

Abelskamp, G. E., \& Santamarinam J. C. (2020). Academia during the COVID-19 pandemic: A study within the geo-science and engineering field. Retrieved from http://alertgeomaterials.eu/data/posts/Abelskamp_and_Santamarina_2020_Academi a_During_COVID19Pandemic.pdf

Al-Hassani, H. Q. M. H., Khakimova, N., \& Alfadaa, F. I. (2020). The factors affecting online purchase intention among university students in Malaysia: A quantitative study during COVID-19. Journal of Critical Reviews, 7(16), 3464-3477.

Ana, A., Minghat, A. D., Purnawarman, P., Saripudin, S., Muktiarni, M., Dwiyanti, V., \& Mustakim, S. S. (2020). Students' perceptions of the twists and turns of e-learning in the midst of the COVID-19 outbreak. Revista Romaneasca Pentru Educatie Multidimensionala, 12(1Sup2), 15-26.

Aristovnik, A., Keržič, D., Ravšelj, D., Tomaževič, N., \& Umek, L. (2020). Impacts of the COVID19 pandemic on life of higher education students: A global perspective. Sustainability, 12(20), 1-34.

Armstrong-Mensah, E., Ramsey-White, K., Yankey, B., \& Self-Brown, S. (2020). COVID-19 and distance learning: Effects on Georgia State University School of Public Health students. Frontiers in Public Health, 8, 1-10. 
Arshad, S., \& Rafique, R. (2016). Personality and creativity as predictors of psychological wellbeing in college students. Pakistan Journal of Psychological Research, 31(1), 139-160.

Barada, V., Doolan, K., Burić, I., Krolo, K., \& Tonković, Ž. (2020). Student life during the COVID19 pandemic lockdown: Europe-Wide Insights. Retrieved from http://www.ehea.info/Upload/BFUG_DE_UK_73_11_6_students_Covid_19_survey_re sults.pdf

BBC News. (2021, January 12). Malaysia declared Covid state of emergency amid political challenges. Retrieved from https://www.bbc.com/news/55625448

Chung, E., Subramaniam, G., \& Dass, L. C. (2020). Online learning readiness among university students in Malaysia amidst COVID-19. Asian Journal of University Education, 16(2), 4658.

Dawood, S. R. S., Ramli, M. W., \& Som, S. H. M. (2020). The resilience of senior citizens in the era of the pandemic: A preliminary study during the movement control order (MCO) in Penang, Malaysia. GEOGRAFI, 8(2), 110-128.

Dhawan, S. (2020). Online learning: A panacea in the time of COVID-19 crisis. Journal of Educational Technology Systems, 49(1), 5-22.

Flesia, L., Monaro, M., Mazza, C., Fietta, V., Colicino, E., Segatto, B., \& Roma, P. (2020). Predicting perceived stress related to the Covid-19 outbreak through stable psychological traits and machine learning models. Journal of Clinical Medicine, 9(10), 117.

Fura, D. L., \& Negash, S. D. (2020). A study on the living experiences of people during the COVID-19 Pandemic: The case of Wolisso town home-stayed university students. $J$ Psychol Psychother, 10(5), 1-11.

Gómez-Galán, J., Martínez-López, J. Á., Lázaro-Pérez, C., \& Sánchez-Serrano, J. L. S. (2020). Social networks consumption and addiction in college students during the COVID-19 pandemic: Educational approach to responsible use. Sustainability, 12(18), 1-17.

Gonzalez, T., de la Rubia, M. A., Hincz, K. P., Comas-Lopez, M., Subirats, L., Fort, S., \& Sacha, G. M. (2020). Influence of COVID-19 confinement on students' performance in higher education. PloS ONE, 15(10), 1-23.

Grubic, N., Badovinac, S., \& Johri, A. M. (2020). Student mental health in the midst of the COVID-19 pandemic: A call for further research and immediate solutions. International Journal of Social Psychiatry, 66(5), 517-518.

Hamid, M. N. S., Ali, R. M., \& Ramli, M. W. (2021). Impak perintah kawalan pergerakan terhadap golongan miskin: Satu analisis cerpen "Kuncitara". Malaysian Journal of Social Sciences and Humanities, 6(2), 1-8.

lqbal, S., Gupta, S., \& Venkatarao, E. (2015). Stress, anxiety \& depression among medical undergraduate students \& their socio-demographic correlates. Indian Journal of Medical Research, 141(3), 354-357.

Joshi, A. R., \& Nagpal, M. (2018). Assessment of perceived stress in postgraduate medical students during training programme. Journal of Clinical \& Diagnostic Research, 12(6), 14.

Kapasia, N., Paul, P., Roy, A., Saha, J., Zaveri, A., Mallick, R., Barman, B., Das, P., \& Chouhan, P. (2020). Impact of lockdown on learning status of undergraduate and postgraduate students during COVID-19 pandemic in West Bengal, India. Children and Youth Services Review, 116, 1-5.

Kaur, G. (2020). Digital life: Boon or bane in teaching sector on COVID-19. CLIO an Annual Interdisciplinary Journal of History, 6(6), 416-427. 
Khan, A. H., Sultana, M. S., Hossain, S., Hasan, M. T., Ahmed, H. U., \& Sikder, M. T. (2020). The impact of COVID-19 pandemic on mental health \& wellbeing among home-quarantined Bangladeshi students: A cross-sectional pilot study. Journal of Affective Disorders, 277, 121-128.

Lan, H. T. Q., Long, N. T., \& Hanh, N. V. (2020). Validation of depression, anxiety and stress scales (DASS-21): Immediate psychological responses of students in the e-learning environment. International Journal of Higher Education, 9(5), 125-133.

Landell, K. (1997). Management by menu. London: Wiley and Sons Inc.

Lee, K. (2020). Social support and self-esteem on the association between stressful life events and mental health outcomes among college students. Social Work in Health Care, 59(6), 387-407.

Mahdy, M. A. A. (2020). The impact of COVID-19 pandemic on the academic performance of veterinary medical students. Frontiers in Veterinary Science. 7, 1-8.

Mahmood, S. (2020). Instructional strategies for online teaching in COVID-19 pandemic. Human Behavior and Emerging Technologies, 1-5.

Ministry of Health Malaysia. (2021). Kenyataan akhbar KPK 23 Mac 2021 - Situasi semasa jangkitan penyakit Coronavirus 2019 (COVID-19) di Malaysia. Retrieved from https://kpkesihatan.com/2021/03/22/kenyataan-akhbar-kpk-22-mac-2021-situasisemasa-jangkitan-penyakit-coronavirus-2019-covid-19-di-malaysia/

Mokhatar, S. N. (2020). Ancaman Covid-19, aktiviti penyelidikan terhenti atau perlu diteruskan?. Universiti Tun Hussein Onn Malaysia News. Retrieved from https://news.uthm.edu.my/ms/2020/05/ancaman-covid-19-aktiviti-penyelidikanterhenti-atau-perlu-diteruskan/

Mokhtari, T., Jamaluddin, R., \& Saad, H. A. (2015). Lifestyle and psychological factors associated with body weight status among university students in Malaysia. Pakistan Journal of Nutrition, 14(1), 18-28.

Mostafa, L. (2020). Egyptian student sentiment analysis using Word2vec during the coronavirus (COVID-19) pandemic. In Hassanien A.E., Slowik A., Snášel V., El-Deeb H., Tolba F.M. (Ed.), International Conference on Advanced Intelligent Systems and Informatics (pp. 195-203). Springer, Cham.

Mpungose, C. B. (2020). Emergent transition from face-to-face to online learning in a South African University in the context of the coronavirus pandemic. Humanities and Social Sciences Communications, 7(1), 1-9.

Nasir, M. I. M., Ramli, M. W., \& Som, S. H. M. (2021). Now look what you've done, COVID-19! The impact on academic survival among postgraduate students in Malaysia. International Journal of Academic Research in Business and Social Sciences, 11(20), 604618.

Nga, H. T. (2020). Demand for part-time job of students today. International Journal of Contemporary Research and Review, 11(09), 21746-21749.

Nik-Ahmad-Zuky, N. L., Baharuddin, K. A., \& Rahim, A. F. A. (2020). Online clinical teaching and learning for medical undergraduates during the COVID-19 pandemic: The Universiti Sains Malaysia (USM) experience. Education in Medicine Journal, 12(2), 75-80.

Ramli, M. W., \& Jamri, M. H. (2021). The impact of COVID-19 pandemic: A closer look at the night market traders' experience in Penang, Malaysia. International Journal of Academic Research in Business \& Social Sciences, 11(1), 741-760. 
Salleh, F. I. M., Ghazali, J. M., Ismail, W. N. H. W., Alias, M., \& Rahim, N. S. A. (2020). The impacts of COVID-19 through online learning usage for tertiary education in Malaysia. Journal of Critical Reviews, 7(8), 147-149.

Saravanan, C., Mahmoud, I., Elshami, W., \& Taha, M. H. (2020). Knowledge, anxiety, fear, and psychological distress about COVID-19 among university students in the United Arab Emirates. Frontiers in Psychiatry, 11, 1-10.

Shahzad, A., Hassan, R., Aremu, A. Y., Hussain, A., \& Lodhi, R. N. (2020). Effects of COVID-19 in e-learning on higher education institution students: The group comparison between male and female. Quality \& Quantity, 1-22.

Sharma, P., \& Devkota, G. (2019). Mental health screening questionnaire: A study on reliability and correlation with perceived stress score. Journal of Psychiatrists' Association of Nepal, 8(2), 4-8.

Siplan, J., \& Holems, S. (2020). Malaysia confirms first cases of coronavirus infection. Reuters. Retrieved from https://www.reuters.com/article/china-health-malaysia/malaysiaconfirms-first-cases-of-coronavirus-infection-idUSL4N29U03A

Sundarasen, S., Chinna, K., Kamaludin, K., Nurunnabi, M., Baloch, G. M., Khoshaim, H. B., Hossain, S. F. A., \& Sukayt, A. (2020). Psychological impact of COVID-19 and lockdown among university students in Malaysia: Implications and policy recommendations. International Journal of Environmental Research and Public Health, 17(17), 1-13.

Toquero, C. M. (2020). Challenges and opportunities for higher education amid the COVID-19 pandemic: The Philippine context. Pedagogical Research, 5(4), 1-5.

United Nations Educational, Scientific and Cultural Organization (UNESCO). (2020). Education: From disruption to recovery. Retrieved from https://en.unesco.org/covid19/educationresponse

United Nations Educational, Scientific and Cultural Organization, International Institute for Higher Education in Latin America and the Caribbean (UNESCO IESALC). (2020). COVID19 and higher education: Today and tomorrow. Retrieved from http://www.iesalc.unesco.org/en/wp-content/uploads/2020/04/COVID-19-EN090420-2.pdf

World Health Organization (WHO). (2020). Timeline of WHO's response to COVID-19. Retrieved from https://www.who.int/news/item/29-06-2020-covidtimeline 